\title{
Organ-on-a-Chip Models for Pancreatic Cancer Research
}

\author{
Tianxiu $\operatorname{Lin}^{1}$
} ${ }^{1}$ Sendelta International Academy, Shiyan Tangtou Avenue Tanghe $2^{\text {nd }}$ Road, Bao'an, Shenzhen, Canton, China,
518000

\begin{abstract}
Pancreatic cancer is the one of lowest survival rate cancer among all kinds of cancer. This is because its early syndromes are very different from other fatal diseases. Although with the development of the detection and management, more than $96 \%$ of the patients cannot live more than 5 years after diagnosis. Survival rate is low for those with malignant disease in the pancreas, because surgical resection at present may cut off the only chance of the cure. Unfortunately, 80-85\% of patients are present with advanced unresectable pathology. Furthermore, pancreatic cancer responds poorly to most chemotherapeutic agents. Therefore, many scientists have devoted tons of efforts into the field of pancreatic cancer. With the development of biotechnology and medicine, a rising tech named Organ-on-a-chip shows astonishing capability of monitoring and modeling cancer. In the following passage, it provides an overview of the advanced technology in research on pancreatic cancer.
\end{abstract}

Keywords: Pancreatic Cancer, Chemotherapeutic Agents, Organ-On-A-Chip

\begin{abstract}
Introduction
\subsection{Epidemiology}

Pancreatic cancer may be the eighth or ninth fatal cancer among most potent cause of cancer-causing death. And it is more obvious around developed countries and areas like Europe, New Zealand, Australia, and North America [1-2]. Moreover, pancreatic cancer is one of the highest mortality rate cancer among all of them and it is exclusively prevalent in the developed countries.
\end{abstract}

\subsection{Pathology}

Pancreatic ductal adenocarcinomas evolve through non-invasive precursor lesions, most typically pancreatic intraepithelial neoplasias, acquiring selected genetic and epigenetic alternations. There are several molecular pathways can intrigue pancreatic cancer. It can evolve from intraductal papillary mucinous neoplasms as well.

According to research, many candidate genes involved in invasive pancreatic adenocarcinomas. The KRAS oncogene is one of the most common abnormal gene mutations. The mechanism of abnormal or mutational activation of the KRAS may be the inactive the tumor-suppressor genes including CDKN2A, TP53, SMAD4, and BRCA2. These genes are related to chromosomal losses, gene amplifications, and telomere shortening [4]

The most frequent cause of the cancer, including pancreatic cancer, is specific genes mutation.

Transcription of the mutant KRAS gene produces an abnormal Ras protein that is "froze" in its activated form, causing the abnormal activation of proliferative and survival signaling pathways.

DPC4 is lost in approximately $50 \%$ of pancreatic cancers, resulting in aberrant signaling by the transforming growth factor $\beta$ (TGF- $\beta$ ) cell-surface receptor.

In a recent analysis, 24 pancreatic cancers indicate that 63 genes altered in the every mature pancreatic-cancer cell. Through bioinformatic analysis, these alterations can be grouped in 12 core signaling pathways [6]. These results, if confirmed in larger studies, would indicate that pancreatic cancer is genetically very complex and heterogeneous. Thus, effective treatments will probably need to attack several targets (with combination regimens) and may require individualized therapy.

\subsection{Risk Factors or other Causes of Pancreatic Cancer}

It remains unknown what trigger the pancreatic cancer. There are several risk factors that may enable a patient to develop pancreatic cancer easier than the others. Genetics is one of the most important factors. From studies, the risk of patients with family history of pancreatic cancer is much higher than those without the family history. The cause behind this is still debatable because gene mutations in each person is different. Through observation, smoking is another contributing factor of pancreatic cancer. There is the solid proof between smoking and the possibility of developing a pancreatic cancer. Some researchers have shown that

This article is published under the terms of the Creative Commons Attribution License 4.0

Author(s) retain the copyright of this article. Publication rights with Alkhaer Publications.

Published at: http://www.ijsciences.com/pub/issue/2020-02/

DOI: 10.18483/ijSci.2253; Online ISSN: 2305-3925; Print ISSN: 2410-4477 
this factor lead to more tobacco and longer smoke. According to studies, some disorders like Diabetes, obesity, and inactivity are also linked with pancreatic cancer. There are less conclusive evidences that high fat diet or nutrient deficiency of lycopene and selenium will increase the risk of pancreatic cancer as well.

\subsection{Classification of Pancreatic Cancer}

Pancreatic cancer, or Pancreatic carcinoma, is a general term for all types of cancer related to the pancreas. In classification, pancreatic cancer can be divided into many sub-types.

Duct adenocarcinoma is the most common one within the field of pancreatic cancer. It takes up nearly around $80 \%$ of all types of pancreatic cancer. It is classified by different degree of dictate-like structure with abundant fibrous interstitium.

Pleomorphic carcinoma, or giant cell carcinoma, is composed of bizarre mononuclear or multinucleate tumor giant cells and even spindle cells.

Adenosquamous carcinoma is caused by squamous degeneration of pancreatic duct epithelium. Commonly, it is made up of adenocarcinoma and squamous cell carcinoma together. It is peculiar to have squamous cell carcinoma occurs alone.

Mucinous carcinoma is the lesion of mucus. Under light microscope, the tumor contains a large amount of mucus, forming a mucus pool.

Acinic cell carcinoma is the rarest one of pancreatic cancer. It takes up only $1 \%$ of the tumor. Others pancreatic cancer like ciliated cell carcinoma, small gland carcinoma, large eosinophilic granulosa cell carcinoma, and islet cell carcinoma are the unusual types of pancreatic cancer as well.

\subsection{Stages}

The American Joint Committee on Cancer tumornode-metastasis classification is most common standard among cancer research, and it is based on assessment of respectability of the cancer tissue [7]. Therefore, pancreatic cancer is measured and staged according to the most recent edition of this classification. Based on this, T1, T2, and T3 tumors are potentially respectable. However, T4 tumors are unresectable. Because T4 tumors involve the superior mesenteric artery or celiac axis,

According to the TNM Staging System (T describes the size of the original tumor and whether it has invaded nearby tissue; $N$ describes nearby lymph nodes that are involved; $M$ describes distant metastasis), the pancreatic cancer can be subdivided into four stages along with the TNM staging system.

\section{Generally}

Under stage I and II: it is respectable through surgery. Because the cancer cells have not spread to other nearby tissue or blood vessels.
Under stage III, it is regarded as threshold respectable stage and, it is regarded as unresectable stage. If it is former, the cancer cells have grown into nearby tissue outside the pancreas. If it is later, the cancer cells have grown outside the pancreas and into one of the blood vessels.

Under stage IV, the cancer cells have migrated into distant organs or areas inside the body where there is no treatment can deal with it.

\subsection{Syndromes}

Patients with pancreatic cancer often have different symptoms. Over many years' studies, the symptoms have been observed and collected during diagnosis. The typically syndromes are listed [8].

1. Jaundice is yellowing of the eyes and skin. Most people with pancreatic cancer will have jaundice as one of their first symptoms.

Jaundice is caused by the accumulation of bilirubin, a dark yellow-brown chemical made by the liver. Generally, the liver releases bile that contains bilirubin. Bile goes through the common bile duct into the intestines, where it helps break down fats. When the common bile duct is blocked, bile can't reach the intestines; therefore, bilirubin accumulates in the body and showcases the symptoms.

\section{Belly or back pain}

3. Weight loss and poor appetite

4. Nausea and vomiting

5. Gallbladder or liver enlargement

\section{Blood clots}

\section{Diabetes}

At its early stage, belly pain, nausea, and vomiting appear the most frequent. Due to its common and indistinguishable character, the patient is usually misdiagnosed as gastropathy, or stomach illness, which results in irreversible severe symptoms when it reaches to terminal stage, becoming unresectable.

\subsection{Therapy}

Radiation Therapy \& Chemotherapy: Like other cancer, radiation is also taken after the surgery in order to minimize the possibility of cancer tissue regrowth. If the patients whose cancers is unresectable, like stage IV, radiation therapy and chemotherapy are used as the major therapy in [9].

Drug Therapy/Targeted Therapy: Growth factors and receptors of the epidermal growth factor receptor (EGFR) family paly indispensable role in during development. Through studied, these factors may abnormally activate which cause the cancer. Thereby one of cancer therapy strategy target the EGFR. The study implied that cetuximab combined with gemcitabine is currently used treatment against pancreatic cancer treatment [10]. of 


\section{Organ-on-a-chip}

Because it is unacceptable to do experiment in vivo to study the pancreatic cancer. Many animal (mostly rodent) models have been used in mechanistic studies. However, it is mostly unsuccessful to translation to humans. The pancreatic cancer is complicated, and the specific mechanisms are unknown and complexity. Under this situation, the identification pathological pathways in human is not only based on animal data. Because animal models cannot create human Pancreatic Cancer, it is necessary to use new and advanced in vitro models that can create the physiology of the human body.

Therefore, the development of Organ-on-a-chip (OOCs), it can be used in this research. What are OOCs? OOCs try to culture and screen pancreatic cell. So it can be used in the process of drug test and experiment because it can maintain higher fidelity and validity in contrast to other method. In the past, model animal tests were usually used in the experiment. although it is an available method that enable help research test whether certain drugs are effects or not. It takes some uninvadable side-effects. Animal test must cost a lot of time and lack of veracity. The human being environment cannot been $100 \%$ represented. So, these may bring out some challenges during inventing drugs. The OOCs allow scientists to monitor human-based physiology. Furthermore, the OOCs model human microenvironment in 3-dimensional way.

So, what purposes does OOCs aim at? Because it can be used to detected subtle changes in microenvironment, OOCs is introduced to drug development, drug delivery, replacement of animal testing, and personal precise medicine. The special advantage of OOCs is that it can precisely simulate environment with high accuracy and flexibility. It can be designed for multiple usages based on this feature. It is commonly accepted that animal testing is most useful method in developing drugs. Laboratory rats are fed and raised for experimental purposes. It is not only cruel but inaccurate because rats' body component is totally different from human being. We still cannot accurately predict what certain drug effect will happen on human. Thus, the process of drug development is time-consuming and lengthy. With OOCs, scientists today will no long need animals for drug testing and that the chip directly monitor the vivid environment of human tissue; the process of drug development will be greatly shortened and becomes effective due to the OOCs.

OOCs are designed to assemble cells into a 3-dimensional structure that is constructed into a simplified while vivid microenvironment in vivo of the corresponding tissue or organ models for research purposes and potential applications.[11] OOCs is a novel technology that was firstly proposed at the year of 2004, the design of lung-on-a-chip. Since then, it shows profound promises in the application in medicine.

When fabricating and designing OOCs, the first step is to determine the targeted organs or tissue being modeled. Then, address the functional characteristics of this particular organ to answer the specific question. The types of human cells used in OOCs are determined mainly by cell's ability to form functional tissues and its availability. Induced pluripotent stem cells (iPSCs), cell lines, and primary cells can be applied differently due to the design of the OOCs.

Organs-on-Chips are fabricated through computer microchip manufacturing techniques that contain microdots or microchannels lined by living cells and tissues cultured within an organ-relevant physical context, which are continuously perfused with life-sustaining culture medium.[12]Photolithography and polydimethylsiloxane (PDMS), a silicon-based organic polymer that is optically clear, non-flammable, and non-toxic, is applied to fabricate the OOCs (Figure 4). The entire process of OOCs fabrication is visualized in video(http://wyss.harvard.edu/technology/human-organ s-on-chips/)

OOCs can be divided into different level to some degrees. From the sequence of animals' cell level: cell, tissue, organ, system, the OOCs can also be classified due to its purpose. Commonly, the OOCs are applied beyond cell-level. The more complex the structure is, the more difficult the fabrication of OOCs is. At the current society, scientists are limited at organ level and is trying to approach the system level. If we can study the systematic OOCs, we will be able to gain insight of how human body function.

\section{Different Organ-on-a-chip in Application}

\section{Lung-on-a-chip}

Organ chips applied to lung which is the first organ in this area. The paper which is about the lung-on-a-chip is published at the year of 2010 (DOI: 10.1126/science.1188302). In this paper, the alveoli responses to inflammatory cytokines and bacteria are modeled. The human lung chip is detailed constructed the functional alveolar capillary. The fabricated microfluidic system contains two closely apposed microchannels separated by a thin flexible membrane made of PDMS. The intervening membrane was covered with ECM (fibronectin or collagen), and human alveolar epithelial cells and human pulmonary microvascular endothelial cells were cultured on the opposite sides of the membrane. The two vacuums provide a physical force that enable the particular motion of stretch, perfectly mimic the breathing motion of lung in vivo. (Figure 5A.)

With the development of on-a-chip, OOCs is applied to different organs to construct model. All of the OOCs 
are used to study different mechanisms.

\section{Challenges:}

To date the OOCs is not used pancreas models which can research recapitulate cancer. Because the complexity either presented by the impact of the immune system or by its multifactorial character. Organ-on-a-chip models is constructed to study diabetes which is common 15].

It is novel and immature to apply the Organ-on-a-chip to pancreas. There is a hardly challenging to combine pancreatic cancer with organ-on-a-chip. Besides, fabricating a well-functioned pancreas-on-a-chip need a lot of time and much money. Due to the unique properties of pancreatic cancer, it will be difficult for scientists to predict the condition or consequences of each experiment. Hopefully, we will be able to culture an OOC that is targeting the pancreatic cancer and find ways to cure it.

\section{References:}

1. Audrey Vincent, Joseph Herman, Rich Schulick, Ralph H Hruban, and Michael Goggins(2011), Pancreatic cancer. Lancet 2011; 378:607-20

2. Stephen Pandol, Anna Gukovskaya, Mouad Edderkoui, David Dawson, Guido Eibl and Aurelia Lugea(2012), Epidemiology, risk factors, and the promotion of pancreatic cancer: Role of the stellate cell, Journal of Gastroenterology and Hepatology 27 (2012) Suppl. 2; 127-134

3. Drouillard A, et al. Épidémiologie du cancer du pancréas. Bull Cancer (2017), https://doi.org/10.1016/j. bulcan.2017.11.004

4. Audrey Vincent, Joseph Herman, Rich Schulick, Ralph H
Hruban, and Michael Goggins(2016), Pancreatic cancer, Nature Review. Disease Primer, Vol. 2, No. 16022

5. Manuel Hidalgo, M.D.(2010), Pancreatic Cancer, N Engl J Med 2010;362:1605-17

6. Jones S, Zhang X, Parsons DW, et al. 11.(2008), Core signaling pathways in human pancreatic cancers revealed by global genomic analyses. Science 2008;321:1801-6.

7. Edge SB, Byrd DR, Compton CC, Fritz 44. AG, Greene FL, Trotti A, eds. AJCC cancer staging manual. 7th ed. New York: Springer, 2010.

8. American Cancer Society, https://www.cancer.org/cancer/pancreatic-cancer/detection-diag nosis-staging/signs-and-symptoms.html

9. American Cancer Society, https://www.cancer.org/cancer/pancreatic-cancer/treating/radiati on-therapy.html

10. Fortunato Ciardiello,M.D.,Ph.D.,and Giampaolo Tortora,M.D.,Ph.D.(2018), Drug Therapy. EGFR Antagonists in Cancer Treatment, N Engl J Med 2008;358:1160-74.

11. Kacey Ronaldson-Bouchard , and Gordana Vunjak-Novakovic(2018), Organs-on-a-Chip: A Fast Track for Engineered Human Tissues in Drug Development. Cell Stem Cell; 22:310-24

12. Bhatia, S.N., and lngber, D.E. (2014). Nat. Biotechnol. 32, 760-772

13. Dongeun Huh, Geraldine A. Hamilton, and Donald E. Ingber(2011), From 3D cell culture to organs-on-a-chips, Trends in Cell Biology, Vol. 21, No. 12

14. [A. Zbinden, J. Marzi, K. Schlünder, et al., Non-invasive marker-independent high content analysis of a microphysiological human pancreas-on-a-chip model, Matrix Biology, https://doi.org/10.1016/j.matbio.2019.06.008

15. Julia Rogal Aline Zbinden Katja Schenke-Layland Peter Loskill, Stem-cell based organ-on-a-chip models for diabetes research $\begin{array}{lll}\text { Advanced Drug } & \text { Delivery } & \text { Reviews, }\end{array}$ https://doi.org/10.1016/j.addr.2018.10.010

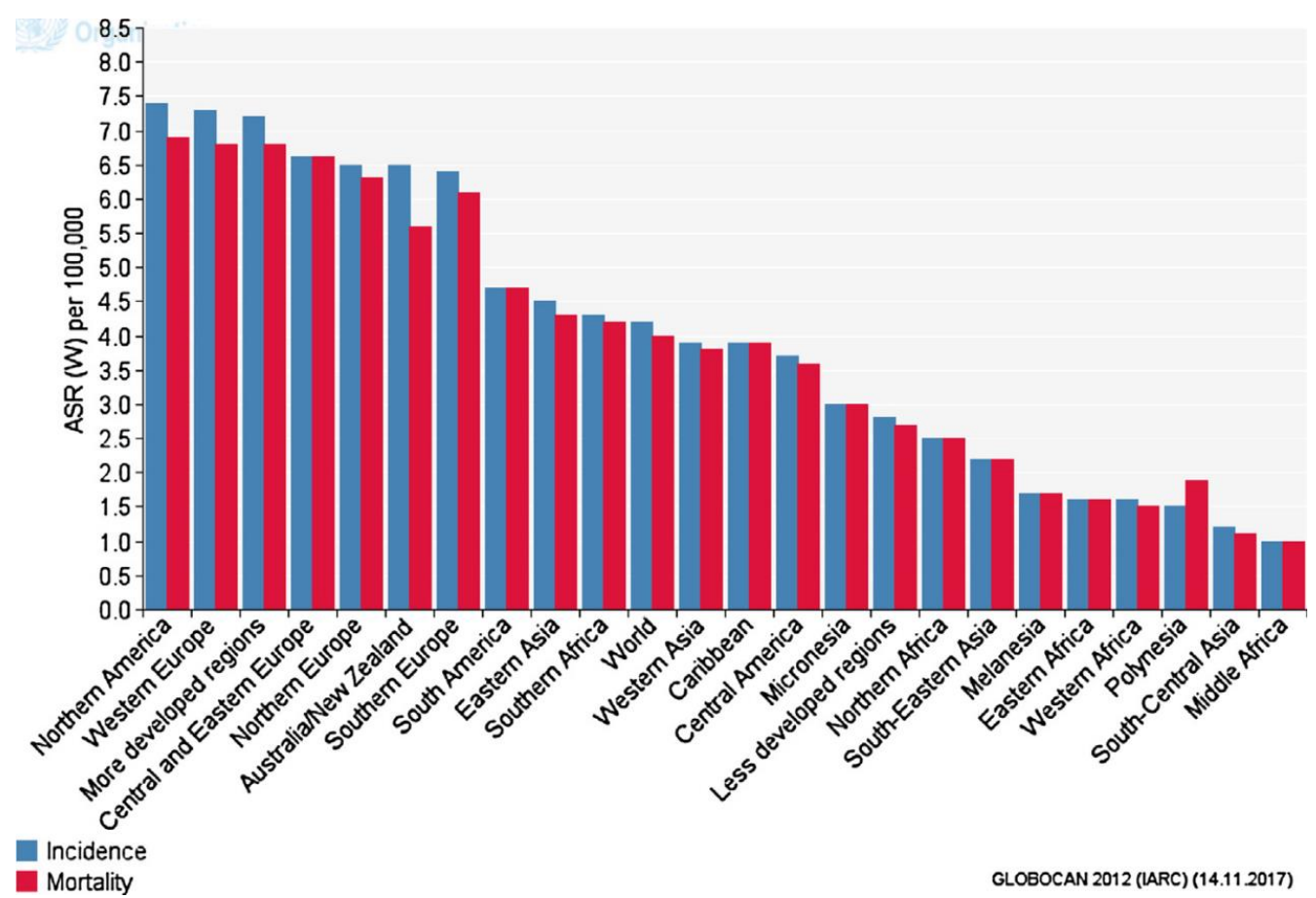

Figure 1. Morbidity and mortality of the world (10,000 Anne, based on the world mortality standard for the population). [3] 


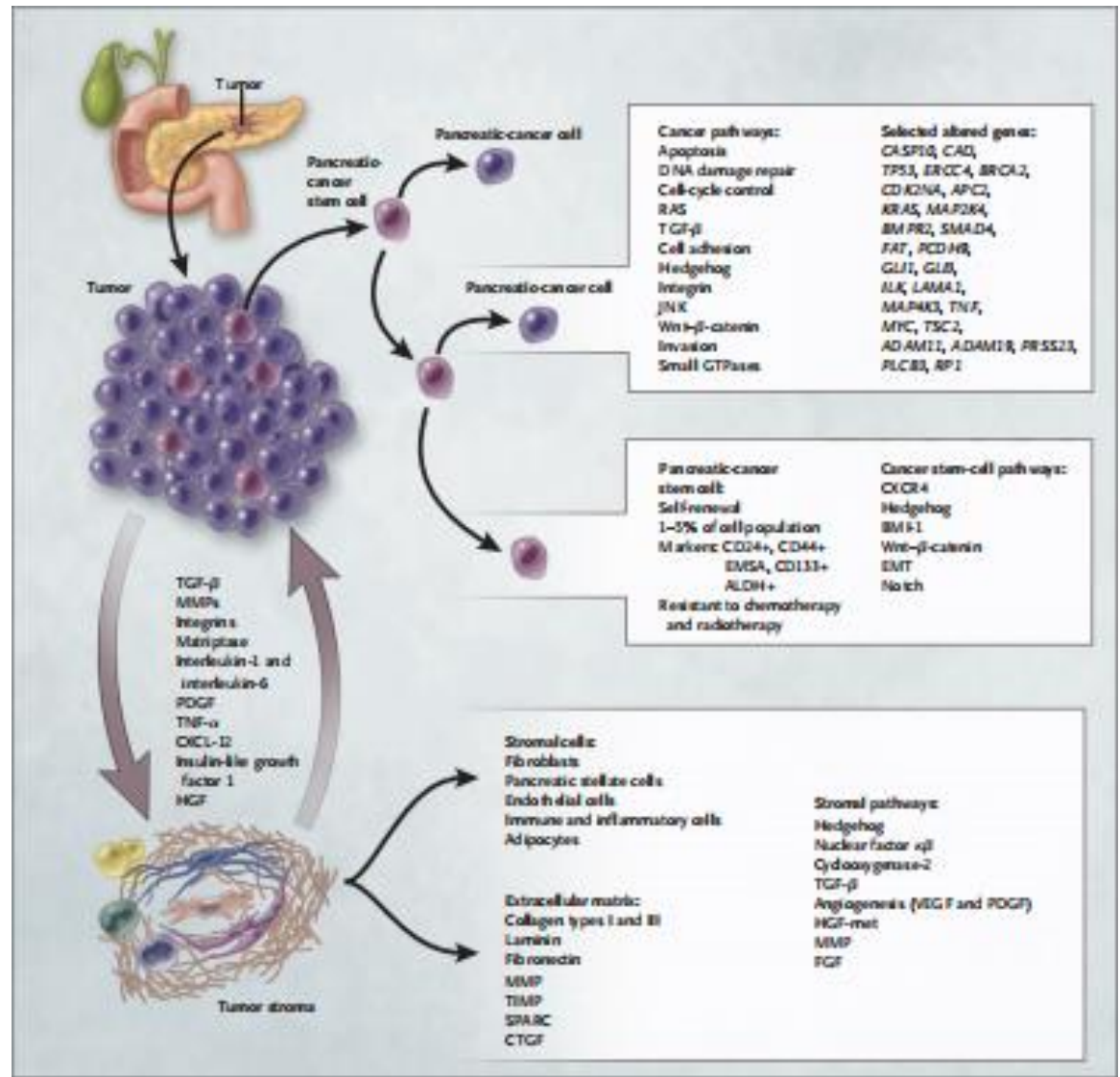

Figure 2. Components of Pancreatic Cancer. [5]

\begin{tabular}{|c|c|c|}
\hline Drug & Molecular Properties & Approved Uses \\
\hline Erlotinib & $\begin{array}{l}\text { Reversible EGFR tyrosine kinase } \\
\text { inhibitor (quinazoline-deriva- } \\
\text { tive molecule) }\end{array}$ & $\begin{array}{l}\text { Erlotinib has been approved by several regulatory agencies worldwide, including } \\
\text { the FDA and the EMEA in the European Union, as monotherapy for the treat- } \\
\text { ment of non-small-cell lung cancer that is refractory to platinum-based chemo- } \\
\text { therapy. More recently, erlotinib has been approved by the FDA and the EMEA } \\
\text { for use in combination with gemcitabine as first-line treatment for advanced } \\
\text { pancreatic cancer. }\end{array}$ \\
\hline Gefitinib & $\begin{array}{l}\text { Reversible EGFR tyrosine kinase } \\
\text { inhibitor (quinazoline-deriva- } \\
\text { tive molecule) }\end{array}$ & $\begin{array}{l}\text { Gefitinib has been approved in various countries for use as third-line treatment of } \\
\text { non-small-cell lung cancer that is refractory to platinum-based and docetaxel- } \\
\text { based chemotherapy regimens. After an accelerated approval process, it was } \\
\text { approved by the FDA in May } 2003 \text { but has been withheld from the U.S. market } \\
\text { since June 2005, as a result of the release of preliminary results of the ISEL trial, } \\
\text { which assessed its use in patients with non-small-cell lung cancer that was re- } \\
\text { fractory to previous platinum-based chemotherapy. Gefitinib has never been } \\
\text { approved in the European Union but is currently on the market in Japan, Korea, } \\
\text { China, and several other Asian countries. It is currently an investigational drug } \\
\text { in the United States and the European Union. }\end{array}$ \\
\hline Cetuximab & $\begin{array}{l}\text { Human-mouse chimeric mono- } \\
\text { clonal antibody (IgGl subtype) }\end{array}$ & $\begin{array}{l}\text { Cetuximab has been approved by several regulatory agencies worldwide, including } \\
\text { the FDA and the EMEA, for the treatment of advanced colorectal cancer that is } \\
\text { refractory to irinotecan-based chemotherapy (alone or in combination with iri- } \\
\text { notecan in the United States but only in combination with irinotecan in the } \\
\text { European Union). Cetuximab in combination with radiotherapy is also ap- } \\
\text { proved for the treatment of locally advanced squamous-cell carcinoma of the } \\
\text { head and neck. }\end{array}$ \\
\hline Panitumumab & $\begin{array}{l}\text { Fully human monoclonal antibody } \\
\text { (IgG } 2 \kappa \text { subtype) }\end{array}$ & $\begin{array}{l}\text { Panitumumab has been approved by several regulatory agencies worldwide, includ- } \\
\text { ing the FDA, as monotherapy for third-line treatment of colorectal cancer that } \\
\text { is refractory to fluoropyrimidines, oxaliplatin, or irinotecan. In December } 2007 \text {, } \\
\text { panitumumab was approved by the EMEA for use in patients with colorectal } \\
\text { cancer who carry a normal, wild-type } K \text {-RAS gene. }\end{array}$ \\
\hline
\end{tabular}

* EGFR denotes epidermal growth factor receptor, EMEA European Medicines Evaluation Agency, FDA Food and Drug Administration, and ISEL Iressa Survival Evaluation in Lung Cancer.

Figure 3.[10] EGFR inhibitors Currently Approved for Cancer Treatment. 


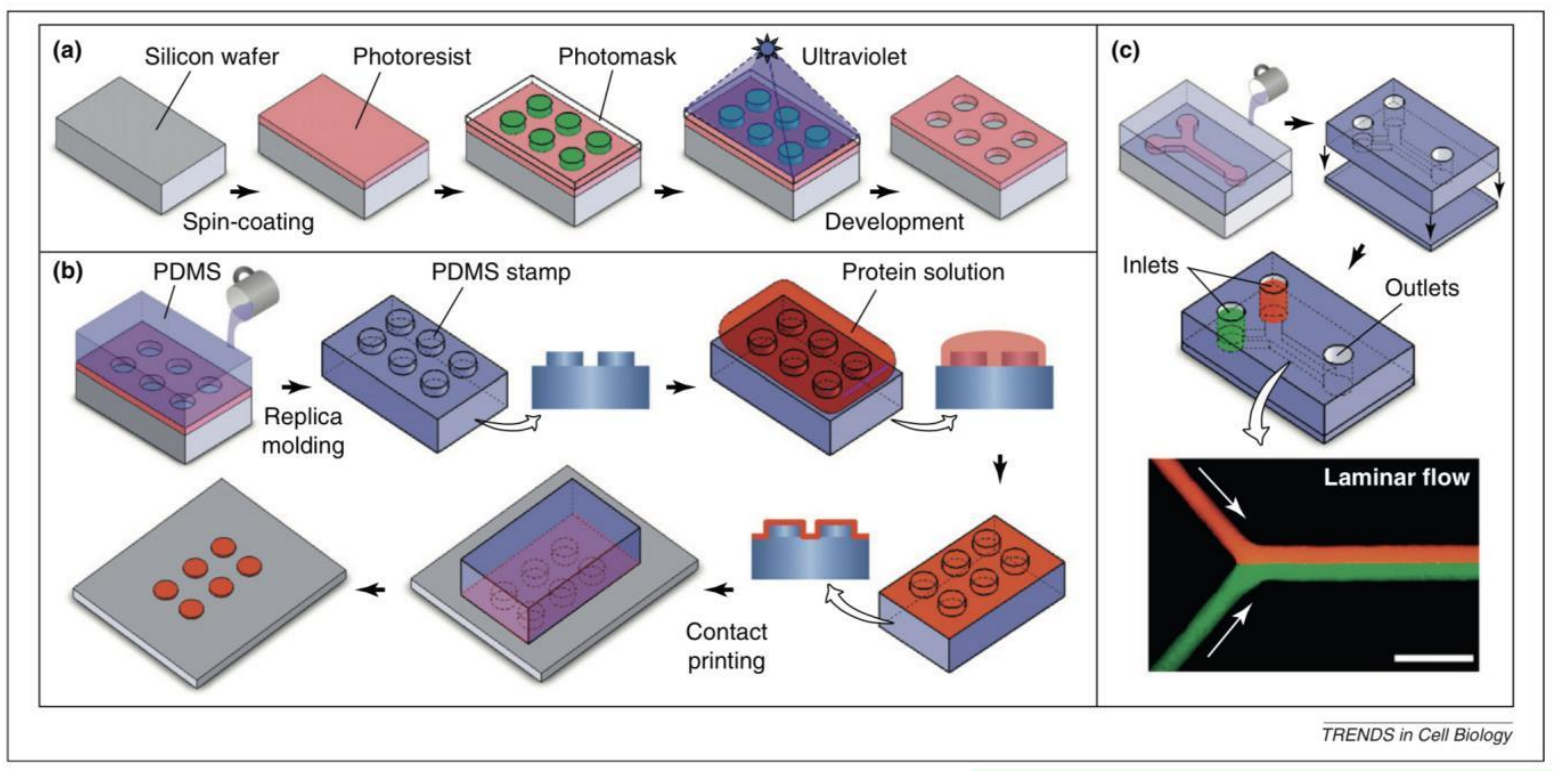

Figure 4.[13] Microengineering technologies used to construct 3D culture systems and organs-on-a-chip
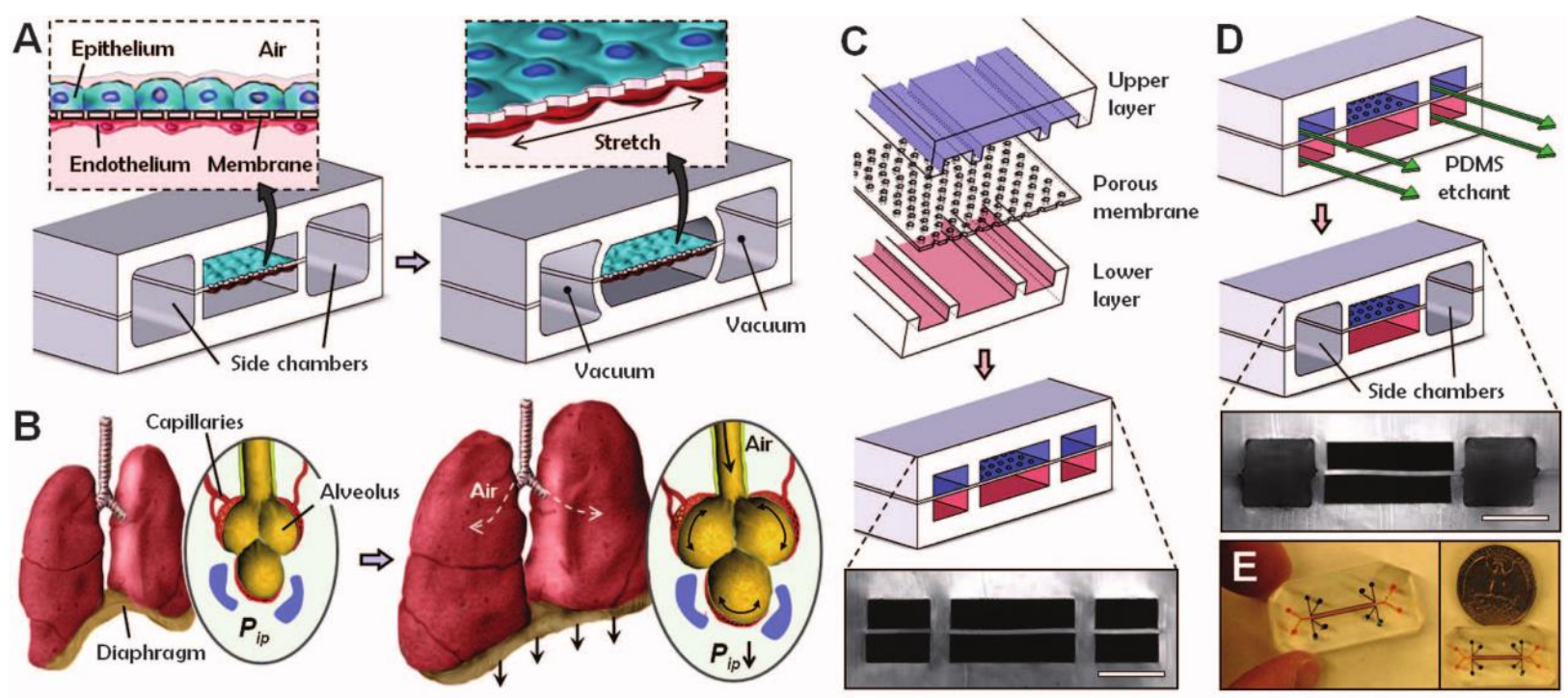

Figure 5.[14] The biologically inspired design of a human breathing lung-on-a-chip microdevice. (A) The microfabricated lung mimic device uses compart-mentalized PDMS microchannels to form an alveolar-capillary barrier on a thin, porous, flexible PDMS membrane coated with ECM. The device recreates physiological breathing movements by applying vacuum to the side chambers and causing mechanical stretching of the PDMS membrane forming the alveolar-capillary barrier. (B) During inhalation in the living lung, contraction of the diaphragm causes a reduction in intrapleural pressure $\left(\mathrm{P}_{\mathrm{ip}}\right)$, leading to distension of the alveoli and physical stretching of the alveolar-capillary interface. (C) Three PDMS layers are aligned and irreversibly bonded to form two sets of three parallel microchannels separated by a 10-mm-thick PDMS membrane containing an array of through-holes with an effective diameter of $10 \mathrm{~mm}$. Scale bar, $200 \mathrm{~mm}$. (D) After permanent bonding, PDMS etchant has flowed through the side channels. Selective etching of the membrane layers in these channels produces two large side chambers to which vacuum is applied to cause mechanical stretching. Scale bar, $200 \mathrm{~mm}$. (E) Images of an actual lung-on-a-chip microfluidic device viewed from above. 
Table 1. Staging of the Pancreatic Cancer

\begin{tabular}{|c|c|c|}
\hline TNM & Subdivision & definition \\
\hline \multirow[t]{4}{*}{$\mathrm{T}$} & $\mathrm{Tx}$ & Tumor cannot be assessed \\
\hline & Tis & Carcinoma in situ \\
\hline & T0 & No evidence of tumor \\
\hline & $\mathrm{T} 1, \mathrm{~T} 2, \mathrm{~T} 3, \mathrm{~T} 4$ & $\begin{array}{l}\text { Size and/or extension of the primary } \\
\text { tumor }\end{array}$ \\
\hline \multirow[t]{5}{*}{$\mathrm{N}$} & $\mathrm{Nx}$ & Lymph nodes cannot be assessed \\
\hline & No & No regional lymph nodes metastasis \\
\hline & N1 & $\begin{array}{l}\text { Regional lymph node metastasis } \\
\text { present;at some sites ,tumor spread to } \\
\text { closest or small number of regional } \\
\text { lymph nodes }\end{array}$ \\
\hline & $\mathrm{N} 2$ & $\begin{array}{l}\text { Tumor spread to an extent } \\
\text { between N1 and N3 }\end{array}$ \\
\hline & N3 & $\begin{array}{l}\text { Tumor spread to more distant or } \\
\text { numerous regional lymph nodes }\end{array}$ \\
\hline \multirow[t]{2}{*}{$\mathrm{M}$} & M0 & No distant metastasis \\
\hline & M1 & Metastasis to distant organs \\
\hline
\end{tabular}

Table 2. Staging of Cancer in general.

\begin{tabular}{|l|l|l|}
\hline \multirow{4}{*}{ Local or resectable } & Stage 0 & Tis, N0. M0 \\
\cline { 2 - 3 } & Stage IA & T1, N0, M0 \\
\cline { 2 - 3 } & Stage IB & T2, N0, M0 \\
\cline { 2 - 3 } & Stage IIA & T3, N0, M0 \\
\cline { 2 - 3 } & Stage IIB & T1, N1, M0; T2, N1, M0; T3, N1, M0 \\
\hline Locally advaced or unresectable & Stage III & T4, any N, M0 \\
\hline Metastatic & Stage IV & anyT, any N, M1 \\
\hline
\end{tabular}

Table 3.[11] Single-Organ OOCs

\begin{tabular}{|c|c|c|c|c|}
\hline $\begin{array}{l}\text { Organ } \\
\text { Type(Functional } \\
\text { Unit) }\end{array}$ & Design Consideration & $\begin{array}{lll}\text { Cell Types } & \text { Used } \\
\text { Currently } & \end{array}$ & Readouts & References \\
\hline Heart & $\begin{array}{l}\text { contractility and } \\
\text { electrical } \\
\text { activity }\end{array}$ & iPSCs & $\begin{array}{l}\text { beat rate, force, } \\
\text { excitation } \\
\text { threshold, maximum } \\
\text { capture } \\
\text { rate, and contractility }\end{array}$ & $\begin{array}{l}\text { Agarwal et al., 2013; } \\
\text { Giacomelli et al., } \\
\text { 2017; Hirt } \\
\text { et al., 2014; } \\
\text { Mannhardt et al., } \\
\text { 2016; Marsano et al., } \\
2016 \text {; } \\
\text { Zhang et al., 2016; } \\
\text { Mathur } \\
\text { et al., 2015; Nunes } \\
\text { et al., } 2013\end{array}$ \\
\hline Lung (alveoli) & $\begin{array}{l}\text { air-liquid interface and } \\
\text { pulmonary drug } \\
\text { absorption }\end{array}$ & Cell lines & $\begin{array}{l}\text { cell imaging and } \\
\text { dissolved } \\
\text { gas concentration }\end{array}$ & $\begin{array}{l}\text { Huh et al., 2010; Long } \\
\text { et al., } \\
2012 \text {; Benam et al., } \\
2017\end{array}$ \\
\hline Liver (hepatic lobule) & $\begin{array}{l}\text { drug metabolism, } \\
\text { cytochrome P450 } \\
\text { interaction, and } \\
\text { hepatocyte } \\
\text { and fifibroblast } \\
\text { co-culture }\end{array}$ & $\begin{array}{l}\text { cell lines and } \\
\text { iPSCs }\end{array}$ & $\begin{array}{l}\text { albumin and urea } \\
\text { production, } \\
\text { cytochrome } \\
\text { P450 enzymatic } \\
\text { activity, } \\
\text { metabolite conversion, } \\
\text { and } \\
\text { drug-induced liver } \\
\text { injury (DILI) }\end{array}$ & $\begin{array}{l}\text { Schepers et al., 2016; } \\
\text { Lee } \\
\text { et al., 2013; Cho et al., } \\
\text { 2010; } \\
\text { Khetani and Bhatia, } \\
2008 \text {; } \\
\text { Lee et al., 2007; } \\
\text { Ramaiahgari } \\
\text { et al., 2014; Rennert et }\end{array}$ \\
\hline
\end{tabular}




\begin{tabular}{|c|c|c|c|c|}
\hline & & & & $\begin{array}{l}\text { al., } \\
2015 ; \text { Ware et al., } \\
2015 ; \\
\text { Bhise et al., 2016; } \\
\text { Domansky } \\
\text { et al., 2010; } \\
\text { Kostadinova } \\
\text { et al., } 2013\end{array}$ \\
\hline $\begin{array}{l}\text { Kidney (nephron and } \\
\text { proximal tubule) }\end{array}$ & $\begin{array}{l}\text { drug clearance and } \\
\text { proximal } \\
\text { tubule epithelium } \\
\text { exposed to } \\
\text { shear stress }\end{array}$ & $\begin{array}{l}\text { primary and cell } \\
\text { lines }\end{array}$ & $\begin{array}{l}\text { fifiltration, } \\
\text { reabsorption, urea } \\
\text { concentration, } \\
\text { epithelial cell } \\
\text { polarization, albumin } \\
\text { transport, glucose } \\
\text { reabsorption, alkaline } \\
\text { phosphatase activity, } \\
\text { and } \\
\text { permeability } \\
\text { glycoprotein } \\
\text { efflflux transporter }\end{array}$ & $\begin{array}{l}\text { Jang et al., 2013; Kim } \\
\text { et al., } \\
2016 \text {; Weinberg et al., } \\
2008\end{array}$ \\
\hline Gut & $\begin{array}{l}\text { drug absorption, } \\
\text { requires a } \\
\text { large surface area via } \\
\text { villi and } \\
\text { microvilli formation, } \\
\text { mucosa } \\
\text { barrier, and symbiotic } \\
\text { bacteria present }\end{array}$ & Cell lines & $\begin{array}{l}\text { transepithelial } \\
\text { transport, } \\
\text { absorption, toxicity, } \\
\text { cytochrome P450 3A4 } \\
\text { isoform drug } \\
\text { metabolism, } \\
\text { and responses to } \\
\text { bacteria }\end{array}$ & $\begin{array}{l}\text { Shah et al., 2016; Kim } \\
\text { and } \\
\text { Ingber, 2013; Esch } \\
\text { et al., } 2012\end{array}$ \\
\hline Brain/BBB & $\begin{array}{l}\text { selective drug } \\
\text { penetration } \\
\text { and interactions } \\
\text { between } \\
\text { endothelium, } \\
\text { pericytes, and } \\
\text { astrocytes/neural cells }\end{array}$ & $\begin{array}{l}\text { primary, cell lines, } \\
\text { and iPSCs }\end{array}$ & $\begin{array}{l}\text { transendothelial } \\
\text { resistance } \\
\text { (TEER), permeability, } \\
\text { and } \\
\text { drug transport }\end{array}$ & $\begin{array}{l}\text { Booth and Kim, 2012; } \\
\text { Brown } \\
\text { et al., 2015; Griep et } \\
\text { al., } \\
2013 \text {; Lancaster et al., } \\
2013 \text {; } \\
\text { Wang et al., } 2017\end{array}$ \\
\hline Skin & $\begin{array}{l}\text { air-liquid interface and } \\
\text { dermal drug } \\
\text { absorption }\end{array}$ & $\begin{array}{l}\text { primary, cell lines, } \\
\text { and iPSCs }\end{array}$ & $\begin{array}{l}\text { transdermal transport, } \\
\text { immunohistochemistry } \\
\text {, and } \\
\text { gene expression }\end{array}$ & $\begin{array}{l}\text { Abaci et al., 2015; } \\
\text { Atac, et al., } \\
\text { 2013; Gledhill et al., } \\
2015 \text {; } \\
\text { Petrova et al., } 2014\end{array}$ \\
\hline Vasculature & $\begin{array}{l}\text { barrier functionality } \\
\text { and } \\
\text { thrombosis }\end{array}$ & $\begin{array}{l}\text { cell lines, human } \\
\text { MSCs, and iPSCs }\end{array}$ & $\begin{array}{l}\text { permeability, response } \\
\text { to } \\
\text { shear stress, TEER, } \\
\text { and } \\
\text { FITC-dextran assay }\end{array}$ & $\begin{array}{l}\text { Fernandez et al., 2016; } \\
\text { Kurokawa et al., 2017; } \\
\text { Moya } \\
\text { et al., } 2013\end{array}$ \\
\hline Cancer & $\begin{array}{l}\text { Tumor } \\
\text { microenvironment and } \\
\text { metastasis }\end{array}$ & Cell lines & $\begin{array}{l}\text { Tumor cell phenotype, } \\
\text { tumor cell } \\
\text { extravasation }\end{array}$ & $\begin{array}{l}\text { Marturano-Kruik et } \\
\text { al., 2018; } \\
\text { Marturano-Kruik et } \\
\text { al., 2015; } \\
\text { Villasante et al., 2014, } \\
\text { 2017a, } \\
\text { 2017b; Villasante and } \\
\text { Vunjak-Novakovic, } \\
\text { 2015; } \\
\text { Chen et al., 2013; Jeon } \\
\text { et al., 2015 }\end{array}$ \\
\hline
\end{tabular}

